\title{
Effects of BA Treatment on Growth and Flowering of Some Vegetative Lines of Gypsophila paniculata L. 'Bristol Fairy'
}

\author{
Motoaki Dor*, Yasuaki Takeda and Tadashi Asahira \\ Laboratory of Vegetable and Ornamental Horticulture, Faculty of Agriculture, \\ Kyoto University, Kyoto 606
}

\begin{abstract}
Summary
Application of $300 \mathrm{ppm} \mathrm{BA} \mathrm{(6-benzylaminopurine)} \mathrm{promoted} \mathrm{flower} \mathrm{initiation} \mathrm{and}$ advanced blooming by about half a month in a heated plastic house under long-day conditions in BF-04, BF-08 and BF-13 vegetative lines of Gypsophila paniculata L. 'Bristol Fairy', but not in BF-20 line. BA treatment also promoted flowering in BF-08 and $\mathrm{BF}-13$ lines even when grown in an unheated plastic house under nutural daylength. BA treatment seemed to substitute for chilling for the induction of flowering, and consequently plants treated with $\mathrm{BA}$ overcame unfavorable growing conditions.

On the other hand, $\mathrm{GA}_{3}$ (gibberellic acid) did not promote flower initiation in any lines grown in an unheated plastic house under natural daylength.

Thus, cut flower production of gypsophila from autumn to winter is possible even in an unheated plastic house under natural daylength by the selection of vegetative lines with low chilling requirement such as $\mathrm{BF}-08$ or $\mathrm{BF}-13$, and the application of $\mathrm{BA}$.
\end{abstract}

\section{Introduction}

Gypsophila cut flowers have been produced throughout the year in Japan by various cropping methods. 'Bristol Fairy' is the leading cultivar in this case. This plant forms rosettes under natural conditions from autumn to winter(8). Once rosettes are formed, they require exposure to a certain amount of chilling to be released from rosettes (physiological dormancy) and ultimately to flower(9).

'Bristol Fairy' often shows non-uniform growth in spite of being vegetatively propagated, and failure to bloom is observed in some cases. Differences in critical photoperiods (3) and/or chilling requirements(1) among vegetative lines of 'Bristol Fairy' appear to be responsible for the non-uniform growth. And it has been noticed that long-day treatment(5) and cold storage of $\operatorname{stocks}(9)$ were effective for

\footnotetext{
Received for publication March 3, 1988.

This study was supported in part by a Grant-inAid for Scientific Reserch of the Ministry of Education, Science and Culture. No. 57480038

* Present address: College of Agriculture, Univertity of Osaka Prefecture, Sakai, Osaka 591.
}

avoiding rosette-like and non-uniform growth.

On the other hand, it was found that repeated treatments with $\mathrm{GA}_{3}$ or $\mathrm{GA}_{4+7}$ did not promote flowering in short days but did so in long days at low night temperature(7). In our preliminary experiments, BA treatment was more effective than $\mathrm{GA}_{3}$ in breaking the rosettes of gypsophila plants that had been exposed to insufficient chilling(9).

The present report concerns the effects of BA treatment on the growth and flowering of some vegetative lines with different chilling requirements, which were selected from 'Bristol Fairy'.

\section{Materials and Methods}

Experiments were carried out on selected vegetative lines with different chilling requirements which had been proved in our previous $\operatorname{report}(1)$.

The selected vegetative lines, $\mathrm{BF}-04, \mathrm{BF}-08$, $\mathrm{BF}-13$ and $\mathrm{BF}-20$, were used. Each line was propagated by terminal cutting on July 1 , and rooted cuttings were transplanted to $7.5 \mathrm{~cm}$ pots on August 1 and pinched on August 15. Finally each plant with two lateral shoots was planted in a $18 \mathrm{~cm}$ plastic pot and grown in 
Table 1. Effects of $\mathrm{GA}_{3}$ and $\mathrm{BA}$ treatments on flowering of some vegetative lines of 'Bristol Fairy' grown in a heated plastic house under long-day conditions.

\begin{tabular}{|c|c|c|c|c|c|c|c|c|}
\hline \multirow{2}{*}{$\begin{array}{c}\begin{array}{c}\text { Line } \\
\text { number }\end{array} \\
04\end{array}$} & \multirow{2}{*}{$\begin{array}{l}\begin{array}{l}\text { Start of } \\
\text { heating }\end{array} \\
\text { Sep. } 30\end{array}$} & \multirow{2}{*}{$\begin{array}{c}\text { Chemical } \\
\text { treatment }^{2}\end{array}$} & \multirow{2}{*}{$\begin{array}{c}\text { Flower bud } \\
\text { emergence } \\
(\%)\end{array}$} & \multirow{2}{*}{$\begin{array}{c}\begin{array}{c}\text { Blooming } \\
(\%)\end{array} \\
19\end{array}$} & \multirow{2}{*}{$\begin{array}{c}\begin{array}{c}\text { Blooming } \\
\text { date }\end{array} \\
-\end{array}$} & \multicolumn{3}{|c|}{ (Days to bloom ${ }^{y}$ ) } \\
\hline & & & & & & ( & - & ) \\
\hline 04 & Sep. 30 & $\mathrm{GA}_{3}$ & 38 & 38 & - & 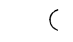 & - & ) \\
\hline 04 & Sep. 30 & $\mathrm{BA}$ & 100 & 100 & Dec. 2 & $c$ & $109 a^{x}$ & ) \\
\hline 04 & Oct. 30 & - & 13 & 13 & - & C & - & ) \\
\hline 08 & Sep. 30 & - & 94 & 88 & Jan. 1 & ( & $139 \mathrm{~b}$ & ) \\
\hline 08 & Sep, 30 & $\mathrm{GA}_{3}$ & 100 & 100 & Dec. 18 & C & $125 \mathrm{c}$ & ) \\
\hline 08 & Sep, 30 & $\mathrm{BA}$ & 100 & 100 & Dec. 3 & c & $110 \mathrm{a}$ & ) \\
\hline 08 & Oct. 30 & - & 81 & 75 & Jan. 2 & C & $140 \mathrm{~b}$ & ) \\
\hline 13 & Sep, 30 & - & 100 & 94 & Dec. 17 & C & $124 \mathrm{~cd}$ & ) \\
\hline 13 & Sep, 30 & $\mathrm{GA}_{3}$ & 94 & 88 & Dec. 17 & ( & $124 \mathrm{cde}$ & ) \\
\hline 13 & Sep, 30 & $\mathrm{BA}$ & 100 & 100 & Dec. 4 & C & $111 \mathrm{a}$ & ) \\
\hline 13 & Oct. 30 & - & 88 & 69 & Dec. 30 & c & $137 \mathrm{~b}$ & ) \\
\hline 13 & Oct. 30 & $\mathrm{GA}_{3}$ & 94 & 94 & Dec. 27 & C & $134 \mathrm{bd}$ & ) \\
\hline 13 & Oct. 30 & $\mathrm{BA}$ & 100 & 88 & Dec. 27 & C & 134 be & ) \\
\hline 20 & Sep, 30 & - & 6 & 6 & - & ( & - & ) \\
\hline 20 & Sep, 30 & $\mathrm{GA}_{3}$ & 6 & 6 & - & ( & - & ) \\
\hline 20 & Sep, 30 & $\mathrm{BA}$ & 19 & 19 & - & ( & - & ) \\
\hline 20 & Oct. 30 & - & 0 & 0 & - & C & - & ) \\
\hline 20 & Oct. 30 & $\mathrm{GA}_{3}$ & 0 & 0 & - & $c$ & - & ) \\
\hline 20 & Oct. 30 & $\mathrm{BA}$ & 31 & 31 & - & ( & - & ) \\
\hline
\end{tabular}

z Chemicals were applied just before the start of heating.

y Days from Aug. 15.

x Mean separation in a column by Duncan's multiple range test, $5 \%$ level.

an unheated plastic house under natural daylength until treated chemically.

Propylene glycol (15\%) solution containing $300 \mathrm{ppm}$ BA (6-benzylaminopurine) was applied by spraying the shoots $(5 \mathrm{ml} /$ plant $)$ on September 30 or October 30. Iso-propyl alcohol (15\%) solution containing $300 \mathrm{ppm} \quad \mathrm{GA}_{3}$ (gibberellic acid) was also applied in the same way on September 30 for comparison. Half of the plants of each line were grown in a heated plastic house, in which the minimum temperature was maintained not below $15^{\circ} \mathrm{C}$ and the daylength was extended to $16 \mathrm{~h}$ by incandescent lamps. The other half were grown in an unheated plastic house under natural daylength.

Flower stalks were harvested from the basal portion of the stems when about $30 \%$ of the florets had bloomed. Cut flower length, cut flower weight and number of nodes to terminal floret and those with lateral inflorescences on the main stem of cut flowers were measured. Cut flower shape was divided into three types as shown in Table 3.
The experiment was terminated on January 31.

\section{Results}

Table 1 shows the results with plants grown in a heated plastic house after chemical treatment. When heating and long-day treatment were started on September 30, BF-04 and BF20 lines hardly bloomed without chemical treatments. In BF-08 and BF-13 lines about $90 \%$ of the shoots bloomed.

$\mathrm{GA}_{3}$ treatment had little effect on the rate of flower bud emergence and blooming, and it advanced the blooming date only in $\mathrm{BF}-08$ line.

BA treatment induced bolting immediately after the start of heating and $100 \%$ of the shoots bloomed in BF-04, BF-08 and BF-13 lines. However, it had only a slight effect on the bolting of BF-20. BA treatment also advanced blooming by about half a month when applied on September 30, but this effect was not clear in BF-13 when treated on October 30. 
Table 2. Effects of $\mathrm{GA}_{3}$ and $\mathrm{BA}$ treatments on flowering of some vegetative lines of 'Bristol Fairy' grown in an unheated plastic house under natural daylength.

\begin{tabular}{|c|c|c|c|c|c|c|c|c|}
\hline $\begin{array}{c}\text { Line } \\
\text { number }\end{array}$ & $\begin{array}{l}\text { Date of } \\
\text { treatment }\end{array}$ & $\begin{array}{l}\text { Chemical } \\
\text { treatment }\end{array}$ & $\begin{array}{l}\text { Flower bud } \\
\text { emergence } \\
\text { (\%) }\end{array}$ & $\begin{array}{c}\text { Blooming } \\
(\%)\end{array}$ & $\begin{array}{l}\text { Blooming } \\
\text { date }\end{array}$ & \multicolumn{3}{|c|}{$\left(\right.$ Days to bloom ${ }^{2}$ ) } \\
\hline 04 & - & - & 0 & 0 & - & C & - & ) \\
\hline 04 & Sep. 30 & $\mathrm{GA}_{3}$ & 0 & 0 & - & C & - & ) \\
\hline 04 & Sep. 30 & $\mathrm{BA}$ & 100 & 31 & - & C & - & ) \\
\hline 08 & - & - & 31 & 0 & - & $c$ & - & ) \\
\hline 08 & Sep. 30 & $\mathrm{GA}_{3}$ & 44 & 0 & - & 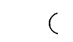 & - & ) \\
\hline 08 & Sep. 30 & $\mathrm{BA}$ & 100 & 81 & Jan. 23 & 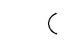 & $161 a^{y}$ & ) \\
\hline 13 & - & - & 50 & 0 & - & c & - & ) \\
\hline 13 & Sep. 30 & $\mathrm{GA}_{3}$ & 50 & 0 & - & C & - & ) \\
\hline 13 & Sep. 30 & $\mathrm{BA}$ & 100 & 88 & Jan. 21 & C & $159 \mathrm{a}$ & ) \\
\hline 13 & Oct. 30 & $\mathrm{GA}_{3}$ & 75 & 0 & - & $C$ & - & ) \\
\hline 13 & Oct. 30 & $\mathrm{BA}$ & 88 & 0 & - & C & - & ) \\
\hline 20 & - & - & 0 & 0 & - & $c$ & - & ) \\
\hline 20 & Sep. 30 & $\mathrm{GA}_{3}$ & 0 & 0 & - & $c$ & - & ) \\
\hline 20 & Sep. 30 & $\mathrm{BA}$ & 0 & 0 & - & c & - & ) \\
\hline 20 & Oct. 30 & $\mathrm{GA}_{3}$ & 0 & 0 & - & c & - & ) \\
\hline 20 & Oct. 30 & $\mathrm{BA}$ & 6 & 0 & - & C & - & ) \\
\hline
\end{tabular}

$z$ Days from Aug. 15.

y Mean separation in a column by Duncan's multiple range test, $5 \%$ level.

When plants were grown in an unheated plastic house under natural daylength, rates of flower bud emergence in BF-04, BF-08, $\mathrm{BF}-13$ and $\mathrm{BF}-20$ lines without chemical treatment were $0,30,50$ and $0 \%$, respectively (Table 2).

$\mathrm{GA}_{3}$ treatment did not greatly promote flowering of any lines.

BA treatment induced bolting in BF-04, $\mathrm{BF}-08$ and BF-13 lines. When BA was applied on September 30, flower buds became visible in early December and flower bud emergence was $100 \%$ in these three lines. In late January, 80 to $90 \%$ of shoots treated with $\mathrm{BA}$ bloomed in $\mathrm{BF}-08$ and $\mathrm{BF}-13$ lines. Flower buds emerged in $88 \%$ of shoots in BF-13 when BA was applied on October 30.

Compared with cut flowers obtained from control plants grown in a heated plastic house under long-day condition, those obtained from BA treated plants were about 30 to $40 \mathrm{~cm}$ shorter and their number of nodes decreased (Table 3). Cut flower weight, number of nodes with lateral inflorescences on the main stem of cut flowers and cut flower shape were not affected by BA treatment when plants were grown in a heated plastic house. Cut flowers from the plants treated with $\mathrm{BA}$ and grown in an unheated plastic house were heavier than those from heated ones.

\section{Discussion}

Exposure to high temperature during summer is known to induce dormancy of gypsophila plants, and consequently they formed rosettes under natural conditions in autumn $(2,8,10)$. Exposure to chilling is necessary for these rosette plants to grow into caulescent plants and to bloom. Different chilling requirements of vegetative lines of 'Bristol Fairy' were discussed in our previous report(1). BF-20 line required the most chilling exposure among four vegetative lines used in this experiment, followed by $\mathrm{BF}-04$. These two lines already became dormant by September 30. BF-08 and $\mathrm{BF}-13$ lines, which required a little chilling, kept their rosette-like growth under low night temperature, short days and low light intensity in autumn. But they had the potential of flowering, because most of their shoots bloomed, when heating and long-day treatment were started on September 30. BA application promoted release from rosette-like grown and consequent flowering in $\mathrm{BF}-04, \mathrm{BF}-08$ and $\mathrm{BF}-13$ lines under both of the cultural conditions mentioned above. Thickening of the stems and development of lateral buds were observed after BA treatment (data not shown). 


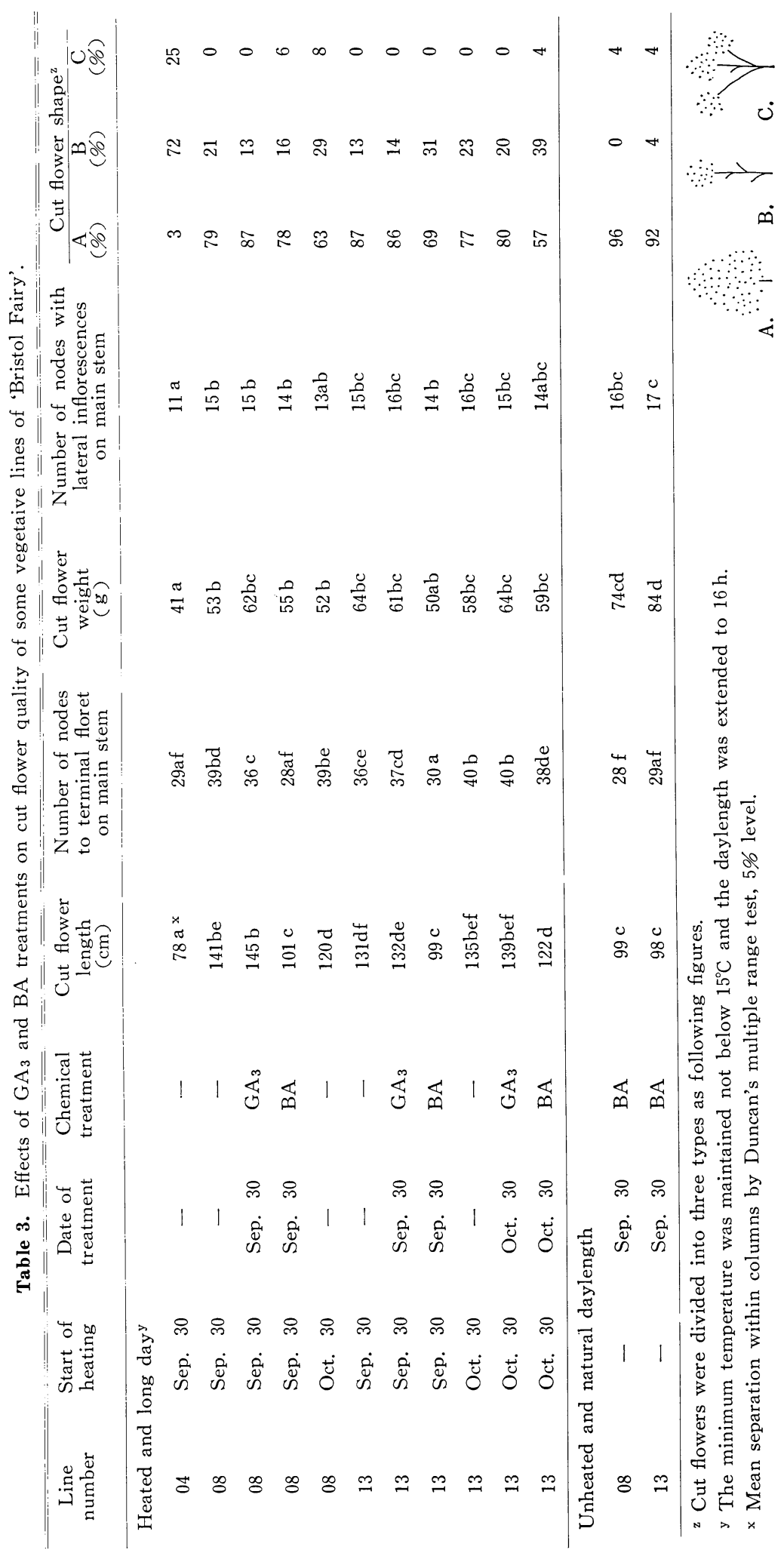


The number of nodes on cut flowers decreased after BA application but it was not affected by cultural conditions after BA treatment. This suggests that vegetative growth of the apical meristem ceased and flower bud formation was initiated immediately after BA treatment.

After BA application flower buds and inflorescences developed even in an unheated plastic house under natural daylength. The daylength became about $13 \mathrm{~h}$ on September 30 and about $12 \mathrm{~h}$ on October 30 including dawn and dusk, and minimum temperature fell below $10^{\circ} \mathrm{C}$ in late October. It has been reported that gypsophila is a long-day plant $(4,6)$ and its critical photoperiod ranges from $12 \mathrm{~h}$ to $18 \mathrm{~h}(3)$. However, plants which had been exposed to enough chilling were able to bloom under $10 \mathrm{~h}$ daylength(10). That is, the critical daylength of gypsophila should be discussed in the light of its previous chilling exposure. And the ranges of temperature for growth and flowering also depend on that. After exposure to enough chilling, gypsophila plants may be able to bloom at shorter daylengths than has been considered as critical. BA treatment seems to substitute for chilling, so that BA treated plants overcame unfavorable conditions for growth and flowering.

It has been reported that BA treatment made flower stalks shorter and weaker, when the plants were grown in a heated plastic house(9). As our results show, when BA was applied to vegetative lines with low chilling requirement such as BF-08 or BF-13, cut flower production of gypsophila from autumn to winter was possible under the temperature conditions of an unheated plastic house without long-day treatment. In this case, the flower stalks of these lines treated with BA were long and thick enough for cut flowers, and their quality was excellent. However, adequate vegetative growth before $\mathrm{BA}$ treatment was necessary for getting cut flowers with good quality.

It is suspected that pinkish-flowered cultivars, 'Flamingo' and 'Red Sea', which require less chilling than any 'Bristol Fairy' vegetative lines, are also profitable for cut flower produc- tion from autumn to winter.

\section{Literature Cited}

1. DOI, M., Y. TAKEDA, and T. ASAHIRA. 1984. Differences in flowering response to low temperature among cultivars of Gypsophila paniculata L. and among vegetative lines of cv. Bristol Fairy. Mem. Coll. Agric. Kyoto Univ. 124: 27-34.

2. DoI, M., T. MoritA, Y. TAKEdA, and T. ASAHIRA. 1984. Influence of high temperature on the flower malformation of Gypsophila paniculata L. Abstr. Japan. Soc. Hort. Sci. Spring Meet. 1984. 292-293. (In Japanese)

3. Kusey, W. E., T. C. Weiler, P. A. Hammer, B. K. Harbaugh, and G. J. WILFRET. 1981. Seasonal and chemical influences on the flowering of Gypshphila paniculata 'Bristol Fairy' selections. J. Amer. Soc. Hort. Sci. 106 : 84-88.

4. Raulson, J. C., S. L. Poe, and F. J. MAROUSKY. 1972. Cultural concepts of Gypsophila paniculata production in Florida. Proc. Florida. State. Hort. Soc. 85 : 423-428.

5. Shillo, R., and A. H. Halevy. 1982. Interaction of photoperiod and temperature in flowering control of Gypsophila paniculata L. Scientia Hort. 16: 385-393.

6. SHIllo, R. 1985. Gypsophila paniculata. p. 83-87. In: HALEVY (ed.) CRC handbook of flowering. CRC Press, Boca Raton, Florida.

7. Shilomo, E., R.Shillo, and A. H. HAlevy. 1985. Gibberellin substitution for the high night temperatures required for the long-day promotion of flowering in Gypsophila paniculata L. Scientia Hort. 26: 69-76.

8. TAKEDA, Y., M. DOI, and T. AsAHIRA. 1981. Influence of temperature, light factors and plant age on induction of rosette of Gypsophila paniculata L., Abstr. Japan. Soc. Hort. Sci. Spring Meet. 1981. 372-373. (In Japanese)

9. TAKEDA, Y M. DOI, and T. AsAhirA. 1981. Influence of growth regulators on release from rosette of Gypsophila paniculata L. Abstr. Japan. Soc. Hort. Sci. Autumn Meet. 1981. 304-305. (In Japanese)

10. TAKEDA, Y., M. DOI, and T. AsAhirA. 1982. Influence of chilling and high temperature exposure on induction of rosette of Gypsophila paniculata L. Abstr. Japan. Soc. Hort. Sci. Autumn Meet. 1982. 366-367. (In Japanese) 


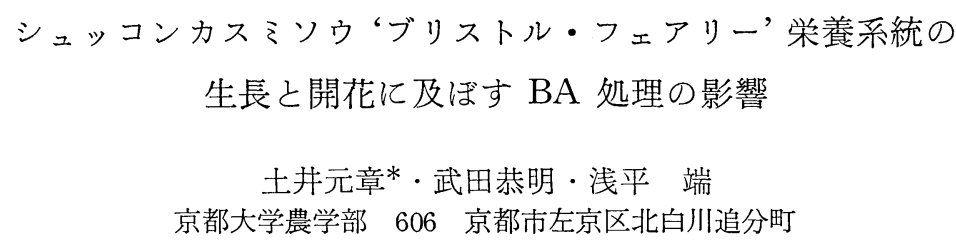

摘 要

シュッコンカスミソウ Gypsophila paniculata L. ‘ブリストル・フェアリー’栄養系統に対して, $300 \mathrm{ppm}$ の BA (6-benzylaminopurine) 処理を行った. その後, 加温長日長のビニルハウスで栽培すると， BF-04, BF08, BF-13 系統においては開花が約半月促進されたが, BF-20 系統では BA 処理による効果は認められなかっ た. 無加温自然日長のビニルハウスで栽培した場合でも， BA 処理により BF-08 系統および BF-13 系統の開花 が促進された. BA 処理は開花に必要な低温遭遇を代替

$*$ 現在 大阪府立大学農学部
し，その結果 BA 処理された植物は不良な環境下でも 生育できることが示された。

一方, 無加温自然日長のビニルハウスでの開花は, $\mathrm{GA}_{3}$ (gibberellic acid) 処理によっては促進されなかっ た.

このように， BF-08 系統拉よび BF-13 系統のよう な低温要求性の小さい栄養系統を選抜し, BA 処理を行 うことによって，秋から冬にかけての無加温自然日長八 ウスでもシュッコンカスミソウの切花生産が可能になる ものと考えられる。 